\title{
Investigation of the Effects of 'Turkish Employees' Cultural Values on Their Career Values
}

\section{Osman USLU ${ }^{1}$}

\begin{abstract}
Based on the question of whether the cultural values of individuals have a role in the building of career values, the current study aims to examine the possible effects of cultural values (power distance, collectivism, and uncertainty avoidance) of Turkish employees on their career values. Accordingly, a quantitative research was designed on employees in different sectors in Kocaeli and Sakarya provinces. The sample of the study consists of 274 employees. Findings indicate that cultural values have partial effects on employees' career values. Each finding was discussed in the context of the relevant literature, and the study was concluded by presenting the theoretical and practical implications and future research suggestions. The study is expected to contribute to the culture and career literature.
\end{abstract}

Key Words: Cultural Values, Career Values, Turkish Employees

\section{Türk Çalışanların Kültürel Değerlerinin Kariyer Değerlerine Etkilerinin İncelenmesi}

\section{$\ddot{O} z$}

Bireylerin kültürel değerlerinin kariyer değerlerinin inşasında rolü olup olmadığı sorusundan hareketle, bu çalışmada Türk çalışanların kültürel değerlerinin (güç mesafesi, toplulukçuluk ve belirsizlikten kaçınma) kariyer değerlerine muhtemel etkilerinin incelenmesi amaçlanmıştır. Buna bağlı olarak Kocaeli ve Sakarya illerinde farklı sektörlerde çalışanlar üzerinde nicel bir araştırma tasarlanmıştır. Araştırmanın örneklemini 274 çalışan oluşturmaktadır. Bulgular kültürel değerlerin, kariyer değerleri üzerinde kısmi etkilerinin olduğunu göstermektedir. Her bir bulgu ilgili yazın bağlamında tartışılmış, bulguların teorik ve pratik imaları ile gelecek araştırma önerileri sunularak çalışma sonlandırılmıştır. Çalışmanın kültür ve kariyer yazınına katkı sağlaması beklenmektedir.

Anahtar Kelimeler: Kültürel Değerler, Kariyer Değerleri, Türk Çalışanlar

\section{Atıf İçin / Please Cite As:}

Uslu, O. (2021). Investigation of the Effects of Turkish Employees' Cultural Values on Their Career Values. Manas Sosyal Arastirmalar Dergisi, 10(3), 1815-1827.

Geliş Tarihi / Received Date: 23.02.2021

Kabul Tarihi / Accepted Date: 11.03.2021

\footnotetext{
${ }^{1}$ Dr. Öğretim Üyesi - Sakarya Üniversitesi İşletme Fakültesi, ouslu@sakarya.edu.tr 


\section{Introduction}

Culture as shared common values, assumptions, norms, and rules of the society (Hofstede, 2001, p. 9-10; Pettigrew, 1979, p.574) affects individuals' perspectives on life, mental worlds, values, and behavior patterns (Lune, 2011, p.82). In this context, one of the phenomena that should be considered when questioning background of human behavior in the organizational environment is culture. Through the cultural codes they have, individuals can express themselves consciously or unconsciously in various environments, shape organizational culture and be influenced by social and organizational culture (Hatch, 2013, p. 159; Maxel, 2013, p. 178). When there is a discrepancy between the cultural values of individuals and the culture of the society they are in or the organization they work for, unwanted behavior patterns may emerge. On the other hand, compatible values can cause individuals to be happy in social life as well as in work-life (Ardıç, Uslu, Oymak, Özsoy, \& Özsoy, 2016, p. 6). In this sense, culture's role seems essential in explaining human behavior both micro and macro levels. Examining the possible effects of cultural values on individual attitudes and behaviors can be useful in explaining the behavior patterns of individuals, as well as being an important tool in detecting and preventing problems that may be encountered in micro-scale organizations. Determining the effects of cultural values on the individual thinking system, attitude, preferences, values, and behaviors provides organizations with proactive thinking skills and also has the potential to guide practical applications.

The cultural values of individuals can also affect their values in many areas such as work, life, family, society, and career (Aycan, \& Fikret Pasa, 2003, p. 32; Schwartz, 1999, p. 25). For instance, individuals with a high degree of acceptance of the unequal distribution of power in a society, in other words, with high power distance values, tend to show greater tolerance to authority and administrators (Hofstede, 2001, p. 107). On the other hand, individuals with individualistic values may care more about their own interests rather than the interests of society (Kağıtcıbaşı, 1997, p. 6). Individuals with a high degree of uncertainty avoidance may tend to professions in which they feel safer in business life, or on the contrary, individuals with a low level of uncertainty avoidance may be more inclined to pursue professions with high risk-taking such as entrepreneurship (Wüst, \& Simic, 2017, p. 139; Hancioğlu, Doğan, \& Sirkıntığlu Yildırım, 2014, p. 910). One of the most fundamental aspects that make life meaningful is to direct a person's life in line with a goal. Although the dynamics of the modern age overwhelm us from time to time, working in jobs that serve our life mission contributes significantly to the long-term well-being of the individual (Wright and Cropanzano, 2000, p. 86). At this point, the person has to work in a job she/he likes and direct her/his career correctly. One of the most necessary determinants of being able to do this is personal career plans. Many factors play a role when individuals create their career plans. Among these, factors such as an individual's personality, education level, family structure, abilities, skills, and cultural level can be listed (Chetana, \& Das Mohapatra, 2017, p. 615-616) Career values are one of the most critical factors that play role in the background of career plans (Aktaş, 2004, p. 43-48). Career values draw a general framework for the job that the individual wants to do. It guides what kind of job and under what conditions an individual wants to perform (Lee, \& Wong, 2004, p. 8). In literature, career values were found to be associated with factors such as personality, ability, upbringing, and education level (Nordvik, 1996). At this point, one of the main issues to be asked is whether the cultural values of the individual have any role in the building of career values. Although it is possible to make some theoretical inferences on this subject, there is not enough empirical accumulation (Marshall, \& Bonner, 2003, p. 283). For this reason, in this study it is aimed to examine the possible effects of Hofstede's cultural values on individuals' career values. In this direction, firstly, the conceptual framework of cultural values and career values is examined. Then, research hypotheses were developed based on the possible theoretical connections of cultural values and career values. Later, the relevant hypotheses were tested empirically, and finally findings were interpreted theoretically, empirically, and practically. When previous studies on the subject are reviewed, it is expected that the study will contribute to the field, since there are not enough studies examining the relationship between cultural values and career values. In addition to the theoretical and empirical contributions of the study, it is expected to provide a practical direction to individuals who have not made their career plans, and who are at the stage of establishing or exploring their career. 


\section{Definition of the Concepts}

\section{Cultural Values}

Societies build cultural values with the habits and behavior patterns that they have passed down from generation to generation for many years. The specific cultural values of Turkish society are issues such as loyalty to the homeland, flag, respect, tolerance, friendship, honor, and family. The most basic study that examines cultural values based on society was conducted by Hofstede (2001). He examined cultural values in terms of individualism-collectivism, uncertainty avoidance, masculinity-femininity, long-short term orientation, and power distance. Known as a patriarchal society, Turkish society is generally collectivist, with high power distance and uncertainty avoidance (Hofstede, 2001). Since this study focuses solely on the values of individualism-collectivism, power distance and uncertainty avoidance, each is outlined below.

Power distance: Power distance is known as the degree to which a cultural member accepts the unequal distribution of power, wealth, and prestige in society or organizations (Hatch, \& Cunliffe, 2013, p. 164; Hofstede, 2001, p. 83). According to Hofstede (2001, p. 80), inequality in society may arise from power, prestige, wealth, status, physical and mental differences. While some community members accept the inequalities that may occur due to the differences mentioned above, some society members do not accept and even reject this inequality (Hatch, \& Cunliffe, 2013, p.164; Sagie, \& Aycan, 2003, p. 465). Individuals who accept the unequal distribution of power are known to have high power distance values, while individuals who do not accept them have low power distance values. These different values of individuals regarding power affect their perspective on life, their way of evaluating events, attitudes, and behaviors (Hofstede, 2001, p. 81-82). For example, employees with high power distance adopt a paternal leadership style in organizations, while employees with low power distance equate paternalism with authoritarianism (Göncü, Aycan, \& Johnson, 2014, p. 36; Aycan, 2006, p. 451). Individuals with low power distance values adopt more democratic and flexible management styles, while individuals with high power distance values can accept more autocratic and rigid management styles (Hoftede, 2001, p. 97-98).

Individualism and collectivism: This dimension is related to the degree to which individuals in a society act independently from other individuals (Hatch, \& Cunliffe, 2013, p. 166). People with individualistic values define themselves as independent units from others, prioritize their own interests, and attach importance to individual success (Bakan, Büyükbeşe, \& Bedestenci, 2004, p. 87). On the other hand, individuals with collectivistic values feel like they are part of a group, see the success of the group more than individual success and care about the interests of the group (Hofstede, 2001). Individualists tend to act in line with their own interests in business and social life, give importance to their own decisions and thoughts rather than group decisions, and pursue individual performance and career goals. On the other hand, people with collectivist values predominantly act towards group decisions, embraces the interests of the group they belong to and struggles for group success.

Uncertainty avoidance: Uncertainty avoidance is related to the degree of tolerance of individuals in a society to innovation, risk-taking, difficult situations and uncertain conditions (Hofstede, 2001, p. 145147). When considered individually, in this context, individuals with a low degree of tolerance to new and different issues, ideas, and conditions are characterized as high uncertainty avoidance, whereas individuals with high tolerance levels are characterized as low uncertainty avoidance (Hatch, \& Cunliffe, 2013, p.164). Individuals with high uncertainty avoidance values generally prioritize the search for security more and have a more emotional nature (Hwang, 2005, p. 154). On the other hand, individuals with low uncertainty avoidance value have a less emotional outlook and tend to take risks more easily (Attia, Shankarmahesh, \& Singhapakdi, 1999, p. 613).

Turkish society's power distance, collectivism, and uncertainty avoidance levels are generally high. (House, Hanges, Javidan, Dorfman, \& Gupta, 2004; Hofstede, 2001, p. 217). On the other hand, although this is the case, of course, not every individual in society has the same values. In general, cultural values have the potential to affect individuals' perspectives, behaviors, attitudes, and other value systems in business and social life. Career values are also a set of values that are likely to be influenced by cultural values (Chetana, \& Das Mohapatra, 2017, p. 615-616).

\section{Career Values}

Career, which can be expressed as the sum of the experiences gained by an individual in business life, covers a large part of a person's life. (Özsoy, 2019, p. 90). In this sense, career can be expressed as an 
important phenomenon for employees in social life as well as in business life. After the development of the human relations approach and the increase of competition between organizations in the 1950s, the importance of career gradually increased and became an even more critical issue in the changing new business world (Sok, Blomme, \& Tromp, 2013, p.227; Berntson, Sverke, \& Marklund, 2006, p. 225). This importance of the subject triggered the investigation of more complex issues such as career path, career anchors, factors affecting career choices, career phases and career success. Detailed investigations about employees' careers seem beneficial in terms of both the individual happiness of the employees and organizational efficiency. There may be many internal and external factors affecting the career choices of employees (Ng, Burke, \& Fiksenbaum, 2008, p. 352). In a broad sense, personality, emotions, thoughts, achievements, values, beliefs, attitudes, expectations, family orientation and social environment are some of these (Özen, 2011, p. 84). All these internal and external factors are important potential precursors in shaping individuals' career values. Perhaps, the cultural values of the society we live in and the reflection of these values on the individual are among the most important factors. Career values seem to be influential in individuals' choice of profession, career success and drawing career path when career values are in harmony with organizational values (Sortheix, Dietrich, Chow, \& Salmelo-Aro, 2013, p. 467). In this context, it seems significant in terms of obtaining information about career values, predicting possible career paths of individuals, planning career types, ensuring person-organization fit, creating employee satisfaction, and increasing organizational and individual performance (Schein, 1990). Career values emerged as a result of the research conducted by Schein (1990), aimed at identifying the underlying issues of employees' career choices. According to Schein, career value means an individual's professional self (Schein, 1990, p. 9). In other words, career value refers to the self that limits, balances, integrates and guides a person's career, and consists of the individual's perceived abilities, basic values, motives and needs. According to Schein, the needs and motives that shape career values are formed in the first years of an individual's life and then guide the person in managing work experiences (Schein, 1990, p. 10). Schein revealed various career values in his work. These career values can be summarized as technical-functional, managerial skills, autonomy, assurance and stability, and an entrepreneurial career. According to Delong (1982), there are different career values such as identity, service, and diversity, in addition to what Schein put forward. All the career values mentioned can be briefly explained as follows:

Technical-functional: Individuals with technical-functional career value want to work only in jobs in their area of expertise and do not want to leave their jobs even if there are some advantages such as salary or rank (Schein, 1990, p. 20)

Management skill: Individuals with leadership and management skills generally adopt promotion, taking responsibility, coming to the fore, working in many specialties rather than a single field and having a voice (Schein, 1990, p. 23)

Autonomy: Individuals with autonomy career value are generally those who do not like organizational standards, adopt to work according to their own rules rather than rules or procedures, and desire autonomy, independence, and seeing themselves as a part of their work (Schein, 1990, p. 27)

Assurance and stability: Individuals with this career value are those who do not want to be dismissed, who adopt a relatively long time in the same workplace, who want to secure themselves and their families (Schein, 1990, p. 28). In Turkish society, they are expected to prefer to work more in public works.

Entrepreneur. Some individuals tend to start their own business, pursue their dreams, and act risky, contrary to assurance and stability. It is possible to express individuals with entrepreneurial career values as individuals who like to be independent and desire to bring their creative side to the forefront (Schein, 1990, p. 29)

Identity: It is possible to describe individuals with identity value as individuals who like to have status and prestige, care about being known with their profession and the institution they work for, and attribute their profession as an identity (Delong, 1982)

Service: Individuals with service career values are those who value serving for others by using their communication, empathy, or helpfulness. These people consider it a virtue to have a share in the success of others (Schein, 1990, p. 30)

Diversity: Unlike the technical-functional career value, individuals with diversity career value want to work in different jobs where they can use different skills rather than working in a specific area of 
expertise. These people who do not like monotonous jobs prefer jobs in which they can use their skills actively (Delong, 1982).

As stated above, the characteristics of the society individuals live in seem to be significantly influential in shaping their career values. At this point, it can be argued that apart from the family and social environment, the cultural values of individuals also play a role in shaping career values. Cultural values that are formed by feeding on society have the potential to affect not only the dynamics of business life such as career, interpersonal relationships, or satisfaction with the manager, but also many areas of social life.

\section{Research Background and Hypothesis Development}

The concept of culture is etymologically based on the concept of agriculture. Agriculture includes cultivation and harvesting of the land and thus obtaining crops. Culture, on the other hand, involves the process of being processed by the mind in the historical process by people living in a certain society and region and to reveal and share new material and spiritual issues (Pettigrew, 1979, p. 579). In this respect, culture basically refers to common values, assumptions, norms, and principles that fall within the scope of sociology's scrutiny and shared by a certain group of people (Mulder, Nunn, \& Towner, 2006, p. 55). Although it is a macro concept, culture includes many materials (eating and drinking styles, dressing styles, designing physical structures, etc.) and spiritual (customs, traditions, customs, habits, ceremonies, etc.) issues (Trice, \& Beyer, 1993, p. 2). For this reason, it is also considered at the micro and meso level. In this respect, culture, which is a social phenomenon, also differs at the individual level. At the individual level, beliefs and value systems also affect people's preferences for work and social life. Therefore, it is possible for individual cultural values to affect career values, which is one of the preferences of employees regarding the way they work and their content (Chetana, \& Das Mohapatra, 2017, p. 615-616; Yi, Ribbens, Fu, \& Cheng, 2015, p.66).

Since cultural values are discussed in terms of the dimensions of power distance, collectivism, and uncertainty avoidance within the scope of the study, firstly, how each cultural value can affect career values is discussed below. Later, related hypotheses were formulated.

Power distance: Individuals with high power distance are aware that power is important in a society. Therefore, it is expected that the importance attributed to power will be more in these societies (Hofstede, 2001 , p. 80). Individuals with high power distance attach importance to both accepting the unequal distribution of power and obtaining power (Hatch, \& Cunliffe, 2013, p. 164). In this respect, it can be expected that individuals with a high power distance will seek a working life in which they will feel stronger. Because the perception of powerlessness can increase the level of obedience to others (Hamilton, \& Biggart, 1985). As a person gains power, she/he will make more effort to be strong because she/he thinks that she/he will be respected more by others (Fragale, Overbeck, \& Neale, 2011, p. 768). Motives such as specializing in their own work, managing others, being known by their own expertise and skills are expected to be higher than those with low power distance (Magee, \& Smith, 2013, p. 160). Because these individuals desire more to gain power through these motives they have. In this respect, individuals with high power distance are expected to attach more importance to career values such as technical-functional, identity and management skills. Therefore, the value of power distance is expected to positively affect the career values of individuals regarding technical-functional, identity and management skills. In contrast, the power distance is expected to affect the service career value negatively. Because individuals who value serving others are generally expected to have less desire to gain power, to have a say in management, or to focus on their own expertise. On the other hand, it is difficult to make a clear deduction for other career values. The main reason for this is that there is not enough empirical knowledge on the subject yet. In this respect, the investigation of the effect of power distance on career values has an "exploratory" nature within the scope of this study.

Collectivism: Individuals who grow up in a collectivist culture tend to act with the motive of "we" rather than "I". These people tend to serve others and societies, prioritize the interests of others rather than themselves, and act in accordance with group expectations rather than individual ambitions and desires (Triandis, 2001, p. 914-917). Since individuals with collective value generally prioritize others rather than themselves (Hatch, \& Cunliffe, 2013, p. 167) and place their own interests in the background, collectivism is expected to affect service career value positively and autonomy career value negatively. Because collectivist individuals tend to be included in a group rather than being autonomous, to prioritize 
the interests of the group and especially group members tend to help others' affairs (Triandis, 2001, p. 914-915). In this context, collectivist cultural value is expected to affect autonomy career value negatively. It is not possible to make clear inferences about other career values. For this reason, the hypothesis about the effects of collectivist values on cultural values will also be established as exploratory.

Uncertainty avoidance: Uncertainty is a situation that stresses and disturbs the individual (Peters, McEwen, \& Friston, 2017, p. 166). For this reason, human nature does not like uncertainties. Especially in some cultures and some individuals this level is much higher. People with very high levels of uncertainty avoidance tend to have a "fixed and regular" job in their career preferences and values. They do not want to work in jobs where employment security is at the initiative of the individuals. In this case, these people are expected to add more meaning to the value of assurance and stability from their career values. Trust and stability are not only narrow in terms of employment, the desire to work in nearby geographies and geographic security is also linked to the value of security and stability. In addition, avoiding uncertainty can be expected to negatively affect entrepreneurship value. Because individuals with a high level of uncertainty avoidance do not want to take risks (Kreiser, Marino, Dickson, \& Weaver, 2010, p. 960), therefore, it is natural that entrepreneurship that requires risk-taking is less of a value in these individuals. It is difficult to make a clear inference regarding other career values due to the lack of empirical knowledge. Therefore, other hypotheses will be exploratory.

As stated above, there is a limited theoretical basis for the relationship between cultural values and career values, while the empirical background is almost nonexistent. In this respect, the expectations set regarding the relationship between cultural values and career values are emphasized only in the context of some career values. For this reason, although partial theoretical expectations are emphasized regarding the research hypotheses, it can be said that the research in general has an exploratory nature. Therefore, research hypotheses were formed non-directional. Relevant hypotheses (within the scope of the main hypothesis and sub-hypotheses) are as follows.

H1: Cultural values affect career values.

H1a: Power distance affects career values.

H1b: Collectivism affects career values.

H1c: Uncertainty avoidance affects career values.

Figure 1 visualizes the theoretical model of the study.

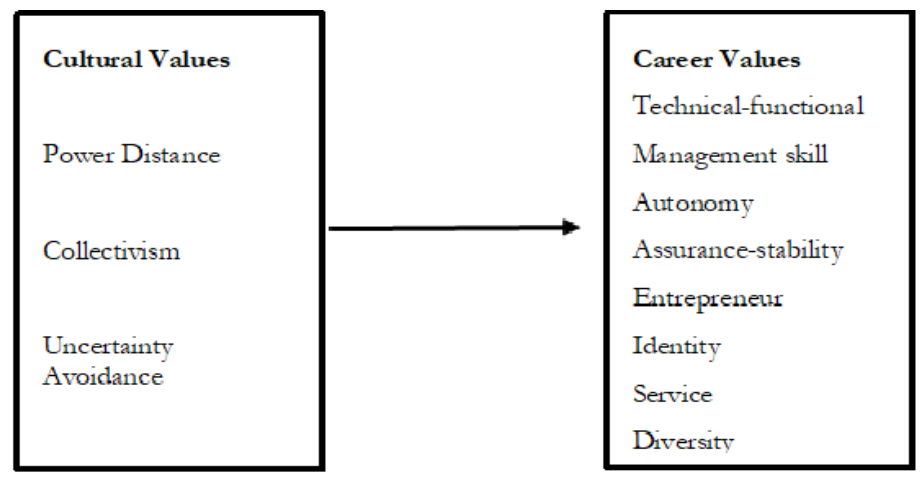

Figure 1. Theoretical Model of the Study

\section{Method}

\section{Design and Sample}

Quantitative analysis methods were used to test the hypotheses of the study. The data required for the research were obtained from the employees of enterprises operating in different sectors in Kocaeli and Sakarya provinces. Kocaeli and Sakarya provinces have constantly migrated because their industries are relatively more developed. Therefore, they have become culturally cosmopolitan cities where people living from all around of Turkey. In this respect, the data obtained from these two provinces were thought to represent Turkish employees' culture. Online survey technique was adopted as a data acquisition method 
in the study. A survey link was sent to the e-mails and social media accounts of approximately 500 potential participants through an online survey application website, and they were asked to participate in the study voluntarily. There were 287 replies to the questionnaire applied with the non-random easy sampling method, and 13 questionnaires were eliminated through control questions. Therefore, the sample of the study consists of 274 participants actively working in the food, electrical-electronics, automotive and education sectors.

\section{Scales}

The questionnaire used in the study consists of three parts: cultural values, career values and demographic questions. Several control questions were added to the questionnaire by the researcher, although they were not found in the original scales. Information about scales is as follows:

Cultural values scale: The scale developed by Yoo, Donthu and Lenartowicz (2011) was used to measure the cultural values of the employees. The scale measures cultural values at an individual level. The original scale consists of 26 items. Within the scope of this research, a total of 16 items were used as collectivism (6), power distance (5) and uncertainty avoidance (5) dimensions. The relevant scale is a 5point Likert type ranging from "I totally disagree" to "I totally agree". The scale was adapted to Turkish by Sayltk (2017). Permission was obtained from the researcher for the use of the adapted scale.

Career values scale: The scale developed by Delong (1982) was used to measure the career values of employees. The scale consists of 38 items and eight dimensions: technical-functional, autonomy, service, identity, entrepreneurial, assurance and stability, management skills and diversity. The scale is 5-point Likert scale ranging from "I totally disagree" to "I totally agree". In Turkish literature, the Turkish version of the scale has been used in different studies and its validity has been tested (Öktem Özgür, 2014).

\section{Participants}

When looking at the general information about the participants, it is seen that the female $(52 \%)$ and male $(48 \%)$ participants are close to each other. Similarly, participants show a balanced distribution in terms of marital status $(53 \%, 47 \%)$. The education level of the participants is very high. When examined, almost half of the participants (51\%) are bachelor graduates, $20 \%$ are primary and high school graduates, $17 \%$ are associate degree graduates and $12 \%$ are postgraduates. The average age of the participants was found to be 34.15 with an average monthly income of 3924.95 TL.

\section{Findings}

\section{Main Statistics and Internal Consistencies}

Factor analysis was applied to the scales first, before proceeding with the analysis for testing the hypotheses. As a result of the analysis, it was observed that the items in both scales were distributed to the relevant dimensions as in the originals. While the total variance explained was $64.98 \%$ for the cultural values scale, it was obtained as $65.75 \%$ for the career values scale. The procedure applied revealed that the scales were valid. After the factor analysis, basic statistics and internal consistency of the scales were checked. Related data are shown in Table 1.

Table 1. Main Statistics and Internal Consistencies

\begin{tabular}{llccc}
\hline Scales & & Mean & SD & Internal consistencies \\
\hline \multirow{3}{*}{ Cultural Values $(\mathbf{0 . 8 7 )}$} & Power Distance & 3.50 & 0.89 & 0.83 \\
& Collectivism & 2.50 & 0.83 & 0.88 \\
& Uncertainty Avoidance & 2.22 & 0.79 & 0.87 \\
\hline \multirow{5}{*}{ Career Values $\mathbf{( 0 . 8 8 )}$} & Technical-functional & 2.68 & 0.86 & 0.81 \\
& Management skill & 2.41 & 0.83 & 0.86 \\
& Autonomy & 2.35 & 0.81 & 0.78 \\
& Assurance-stability & 2.09 & 0.87 & 0.83 \\
& Entrepreneur & 2.27 & 0.74 & 0.68 \\
& Identity & 2.42 & 0.83 & 0.79 \\
& Service & 2.03 & 0.68 & 0.81 \\
& Diversity & 2.37 & 0.68 & 0.75 \\
\hline
\end{tabular}


Internal consistency values of both cultural values and career values scales were obtained at quite reliable levels. The subscales of the relevant scales also seem generally satisfactory. These findings reveal that the scales used in the context of the research are valid and reliable. When the cultural values are examined, the highest value of the participants was the power distance. While collectivism was moderate, uncertainty avoidance appeared to below the average. When the dimensions that constitute career values are examined, it is seen that the average of the participants is medium and low in general.

\section{Hypothesis Testing}

Multiple regression analysis was used to test the hypotheses. In the model, power distance, collectivism and uncertainty avoidance cultural values are considered as independent variables and each career value as dependent variables. Thus, the effects of cultural values on career values were examined in 8 different models. Relevant analyzes are presented in Table 2.

Table 2. Multiple Regression Findings

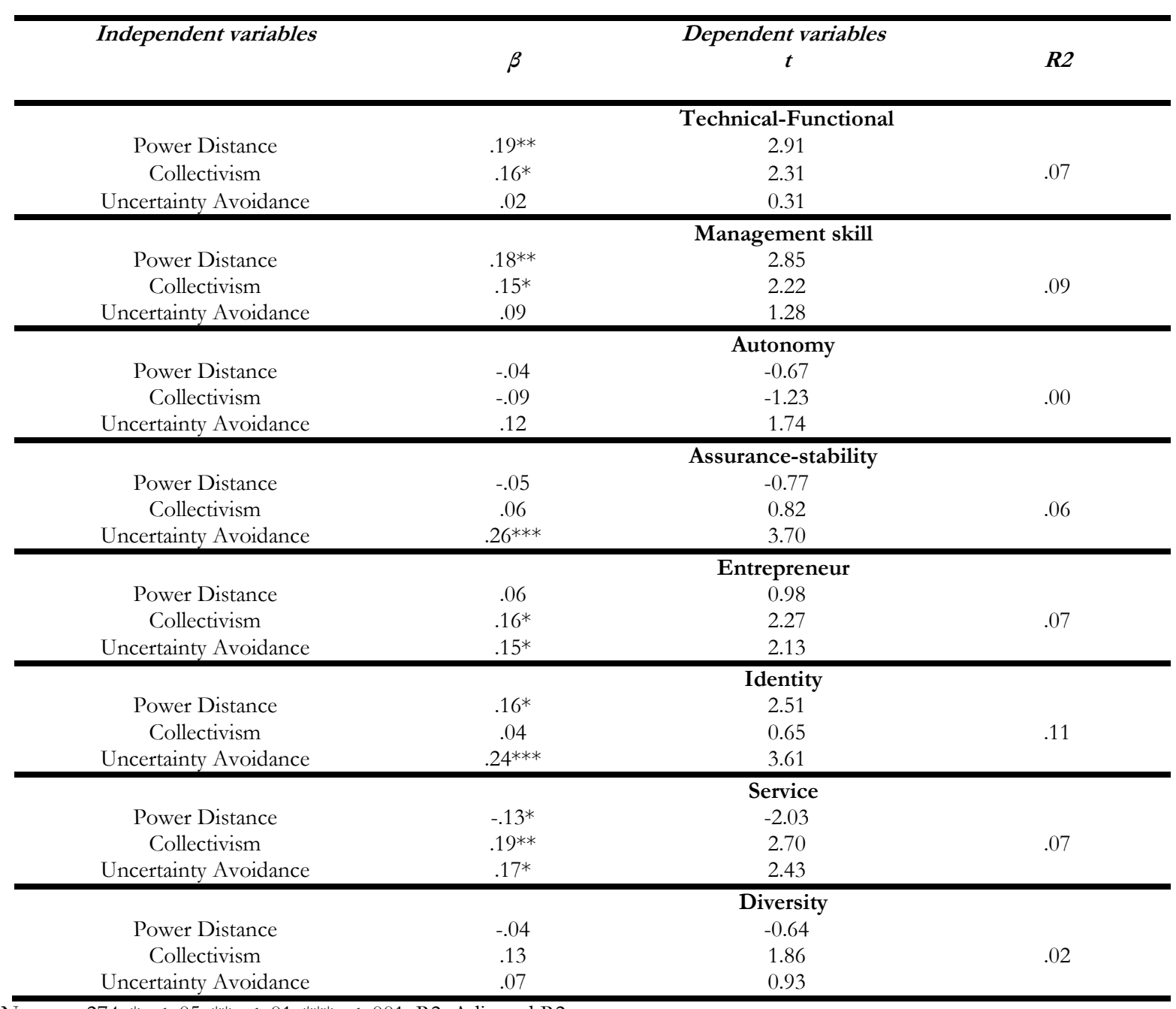

Note: $\mathrm{n}=274 .{ }^{*} \mathrm{p}<.05,{ }^{* *} \mathrm{p}<.01,{ }^{* * *} \mathrm{p}<.001 ; \mathrm{R} 2:$ Adjusted R2.

According to the findings, as expected, employees' power distance values affect technical-functional, management skills and identity career values positively and service career value negatively. On the other hand, no significant effects of power distance value on autonomy, assurance and stability, entrepreneurship and diversity career values were found. While collectivism cultural value positively affects technical-functional, management skills and service career values, its effects on other career values were found to be insignificant. Finally, employees' values of uncertainty avoidance positively affect the assurance and stability, entrepreneurship, identity, and service career values. On the other hand, there were no significant effects of uncertainty avoidance on technical-functional, management skills, autonomy, and diversity career values. Thus, findings partially support H1, H1a, H1b and H1c. 


\section{Discussion and Conclusion}

In current study, it is aimed to examine the effects of cultural values of Turkish employees on their career values. The findings obtained as a result of the research conducted for this purpose reveal that the power distance, collectivism, and uncertainty avoidance, which characterize Turkish society, have a partial effect on individuals' career values. Power distance affects individuals' technical-functional, management skills and identity career values positively and service career value negatively. Individuals with high power distance are generally those who have a higher desire to gain power, use power, solve problems through power (Fragale, Overbeck, \& Neale, 2011, p. 768). These people also attach extreme importance to prestige and status. The technical-functional, management skills and identity characteristics of individuals with high power distance such as being in top management, actively participating in decisions, seeking prestige and status (Magee, \& Smith, 2013, p. 160) may have been effective in shaping their career values. In this context, the positive effect of power distance on relevant career values seems natural. There are contradictions between the motives of individuals with high power distance and the service career value. Accepting to serve for others is not usual for individuals who attach importance to power, who want to have a say in management, and to dominate others. On the contrary, it is more meaningful that individuals who do not care about power desire to serve others. Therefore, the negative effect of the power distance value on the service career value also seems natural. The power distance value was not correlated with autonomy, assurance and stability, entrepreneurial and diversity career values. Findings indicate that collectivism positively affects technical-functional, management skills, entrepreneurial and service career values. The tendency to serve for others, help others, and exhibit other public behaviors coincide with the cultural tendencies of collectivist individuals (Hatch, \& Cunliffe, 2013, p. 167; Triandis, 2001, p. 914-917). Because collectivist individuals display characteristics that care more about the interests of the community rather than their own interests, are prone to teamwork, and are especially dependent on their own group. The positive impact of collectivism on service career value is as expected in this context. Collectivist individuals tend to stand out, take responsibility for the group they belong to, lead them, and adhere to the group's decisions. These characteristics coincide with management skills and entrepreneurship career values. Since collectivistic values may have played a role in the development of individuals' management and entrepreneurship values, it can be inferred that collectivism positively affected the mentioned career values. Contrary to expectations, collectivism did not significantly affect autonomy career value. The findings show that collectivism negatively affects autonomy as expected, but this effect was not statistically significant. Uncertainty avoidance, as expected, positively affects assurance and stability career value. Individuals with a high level of uncertainty avoidance tend to be employed for a long time in the same workplace, to secure themselves, and to lead a stable and unsettled life because they do not want to take risks (Kreiser, Marino, Dickson, \& Weaver, 2010, p. 960). These individuals generally exhibit a high normative commitment to the institution they work for and have a lower intention to leave than other individuals (Saraç, \& Raina, 2018, p.172). In this sense, it is natural that uncertainty avoidance positively affects the assurance and stability of career value. Other findings suggest that uncertainty avoidance positively affects identity and service career values. Especially the finding regarding identity career value seems quite logical. Individuals who attach importance to prestige and status, who are motivated to gain identity with their own expertise, organization, and profession, do not want to take risks and have a stable career understanding are overlapping issues. The positive effect of uncertainty avoidance on identity career value can be explained in this way. Uncertainty avoidance positively affected entrepreneurship career value with low intensity. This finding was essentially contrary to what was expected. Under normal conditions individuals who avoid taking risks are expected to have low entrepreneurial values. However, a different finding was obtained in the context of the current study. Perhaps, it can be thought that fears such as dismissal and assurance and stability lead individuals to establish their own businesses consciously or subconsciously. Here it is necessary to focus on the exact meaning of risk-taking and to consider it contextually. As a result, the desire to provide assurance and stability is actually risk aversion, and one may choose to be an entrepreneur simply by considering working under the command of others as a risk. In this context, being an entrepreneur can actually be perceived as avoiding risk. When all findings are considered, it is concluded that cultural values have partial effects on career values in the context of the current study.

The findings of the study offer various theoretical and practical implications. First of all, this study proves that cultural values are an important factor influencing career values, even the effects are partial. Culture somehow affects the values of individuals in different fields. By defining cultural values and 
determining their connections with career values, employment areas that employees are likely to be successful in can be determined. In this sense determining cultural values may be useful for individuals who have not planned their career goals yet and are at discovering and establishing career stages. On the other hand, rotations, ranks and rewarding practices can be implemented in organizations by determining the types of professions in which current employees will be successful. Cultural value analysis can be done before these applications are made. Since cultural value career value harmony will make employees happy in the workplace, it will also contribute to the increase of individual and organizational performance.

The sample of this study consists of people working only in Kocaeli and Sakarya provinces. The sample is assumed to represent the Turkish employees, because of the fact that Kocaeli and Sakarya provinces are cosmopolitan cities where people migrated to work from all over Turkey. On the other hand, the fact that the study only includes Turkish employees can be considered as a limitation. Therefore, it is difficult to generalize the findings in the context of the current study to other cultures of the world. Similarities can be observed in terms of employees in Asia and the Middle East geography, which are close to Turkish cultural values. In future studies, collecting data from other cosmopolitan provinces such as Istanbul, Izmir and Ankara may be beneficial in terms of obtaining more reliable results. Making comparative studies by creating samples from Western culture seems significant in terms of scientific knowledge. In this study, culture measurement was carried out through a questionnaire. In fact, it can be considered as another limitation in this case. Because the complex nature of culture makes it difficult to measure. For this reason, it may be beneficial to adopt mixed methods by making use of qualitative data collection techniques such as interviews in future studies. The findings of this research, conducted with exploratory intent, were of course made with the motive of contributing to the literature. However, it is evident that many more theoretical and empirical studies are needed for the interaction of cultural values and career values.

\section{Ethical Declaration}

In the writing process of the study titled 'Investigation of the Effects of Turkish Employees' Cultural Values on Their Career Values", there were followed the scientific, ethical, and the citation rules; was not made any falsification on the collected data and this study was not sent to any other academic media for evaluation. Ethics committee decision: Sakarya Üniversitesi Etik Kurulu, Date: 03/02/2021, No: 09.

\section{References}

Aktaş, H. (2004). The importance of career anchor notion for an effective career planning and an example application at Turkish Air Force Undergraduate and Graduate Schools (Yüksek Lisans Tezi). Marmara Üniversitesi, Sosyal Bilimler Enstitüsü, İstanbul.

Ardıç, K., Uslu, O., Oymak, Ö., Özsoy, T. \& Özsoy, E. (2016). Comparing person organization fit and person job fit. Journal of Economics and Management, 25(3), 5-13.

Attia, A., Shankarmahesh, M. N., \& Singhapakdi, A. (1999). Marketing ethics: a comparison of American and Middle Eastern marketers. International Business Review, 8(5-6), 611-632.

Aycan, Z. \& Fikret Pasa, S. (2003). Career Choices, Job Selection Criteria, and Leadership Preferences in a Transitional Nation: The Case of Turkey. Journal of Career Development, 30(2), 129-144.

Aycan, Z. (2006). Paternalism: Towards conceptual refinement and operationalization. In K. S. Yang, K. K. Hwang, \& U. Kim (Eds.), Scientific advances in indigenous psychologies: Empirical, philosophical, and cultural contributions (pp. 445-466). London: Cambridge University Press.

Bakan, İ., Büyükbeşe, T. \& Bedestenci, H. Ç. (2004). Örgüt Sirlarmn Çöqümünde Örgüt Kültürü: Teorik ve Ampirik Yaklaşım. Bursa: Alfa Aktüel Yayınları.

Berntson, E., Sverke, M., \& Marklund, S. (2006). Predicting perceived employability, human capital or labor market opportunities. Economic and Industrial Democracy, 27(2), 223- 244.

Chetana, N., \& Das Mohapatra, A. K. (2017). Career planning and career management as antecedents of career development: a study. Asian Journal of Management, 8(3), 614-618.

DeLong, T. J. (1982). The career orientation of MBA alumni: A multi-dimensional model. In R. Katz (Ed.), Career issues in human resource management. Englewood Cliffs, NJ: Prentice-Hall.

Fragale, A. R., Overbeck, J. R., \& Neale, M. A. (2011). Resources versus respect: Social judgments based on targets' power and status positions. Journal of Experimental Social Psychology, 47, 767-775.

Göncü, A., Aycan, Z., \& Johnson, R. E. (2014). Effects of Paternalistic and Transformational Leadership on Follower Outcomes. The International Journal of Management and Business, 5(1), 36-58.

Hamilton, G. G., \& Biggart, N. W. (1985). Why People Obey: Theoretical Observations on Power and Obedience in Complex Organizations. Sociological Perspectives, 28(1), 3-28. 
Hancıoğlu, Y., Doğan, Ü. B., \& Sırkıntıoğlu Yıldırım, Ş. (2014). Relationship between Uncertainty Avoidance Culture, Entrepreneurial Activity and Economic Development. Procedia-Social and Behavioral Sciences, 150, 908916.

Hatch, M. J. \& Cunliffe, A. L. (2013). Organization Theory: Modern, Symbolic, and Postmodern Perspectives. UK: Oxford University Press.

Hosftede, G. (2001). Culture's Consequences: Comparing Values, Behaviors, Institutions, and Organizations Across Nations. (2nd Ed.), USA: Sage Publications.

House, R. J., Hanges, P. J., Javidan, M., Dorfman, P., \& Gupta, V. (2004). Culture, Leadership, and Organizations: The GLOBE Study of 62 Societies. London: Thousand Oaks, CA: Sage.

Hwang, Y. (2005). Investigating enterprise systems adoption: uncertainty avoidance, intrinsic motivation, and the technology acceptance model. European Journal of Information Systems, 14, 150-161.

Kağıtcıbaşı, Ç. (1997). Individualism and Collectivism. In Handbook of Cross-cultural Psychology: Social Behavior and Applications. Berry, J. W., Segall, M. H., \& Kağıtcıbaşı, Ç. (eds.), Allyn and Bacon.

Keiser, P. M., Marino, L. D., Dickson, P., \& Weaver, K. M. (2010). Cultural Influences on Entrepreneurial Orientation: The Impact of National Culture on Risk Taking and Proactiveness in SMEs. Entrepreneurship Theory and Practice, 34(5), 959-984.

Lee, S. H., \& Wong, P. K. (2004). An exploratory study of technopreneurial intentions: A career anchor perspective. Journal of Business V enturing, 19, 7-28.

Lune, H. (2011). Understanding Organizations. UK: Polity Press.

Magee, J. C., \& Smith, P. K. (2013). The Social Distance Theory of Power. Personality and Social Psychology Review, 12(2), 158-186.

Marshall, V. \& Bonner, D. (2003). Career anchors and the effects of downsizing: implications for generations and cultures at work. A preliminary investigation. Journal of European Industrial Training, 27(6), 281-291.

Maxel, O. J. M. (2013). Managerial Challenge to Cross Cultural Management of Diversity. European Journal of Business and Management, 5(20), 177-185.

Mulder, M. B., Nunn, C. L., \& Towner, M. C. (2006). Cultural Macroevaluation and the Transmission of Traits. Evolutionary Anthropology, 15, 52-64.

Ng, E. S. W., Burke, R. J., \& Fiksenbaum, L. (2008). Career choice in management: findings from US MBA students. Career Development International, 13(4), 346-361.

Nordvik, H. (1996). Relationship between Holland's vocational typology, Schein's career anchors and Myers Briggs' types. Journal of Occupational and Organizational Psychology, 69, 263-275.

Öktem Özgür, A. (2014). Kariyer Değerleri ve Algzlanan İstibdam Edilebilirlik. Arasindaki İlişkinin İncelenmesi (Yüksek Lisans Tezi). Dokuz Eylül Üniversitesi, Sosyal Bilimleri Enstitüsü, İzmir.

Özen, Y. (2011). Kşisel Sorumluluk Bağlamında kariyer Seçimini Etkileyen Sosyal Psikolojik Faktörler. Eğgitim ve İnsani Bilimler Dergisi: Teori ve Uygulama, 2(3), 81-96.

Özsoy, E. (2019). Kariyer Başarısı. İçinde. Kariyer: Temel kavramlar, yönetimi, güncel konular (Editörler E. Kaygın., ve Y. Zengin). Eğitim Yayınevi. Konya.

Peters, A., McEwen, B. C., \& Friston, K. (2017). Uncertainty and stress: Why it causes diseases and how it is mastered by the brain. Progress in Neurobiology, 156, 164-188.

Pettigrew, A. (1979). On studying organizational culture. Administrative Science Quarterly, 24(4), 570-581.

Sagie, A. \& Aycan, Z. (2003). A Cross-Cultural Analysis of Participative Decision-Making in Organizations. Human Relations, 56(4), 453-473.

Saraç, M., \& Raina, R. (2018). Organizational Commitment and Intention to Leave: The Moderating Role of Uncertainty of Avoidance. 38th International Academic Conference. Prague, 11-14 June.

Saylık, A. (2017). Okul müdürlerinin paternalist (babacan) liderlik davranısllar ile Hofstede'nin kültür boyutlar arasindaki ilişki (Doktora Tezi). Ankara Üniversitesi, Eğitim Bilimleri Enstitüsü, Ankara.

Schein, E. (1990). Career Anchors: Discovering Your real V alues. San Francisco: Jossey-Bass Pfeiffer.

Schwartz, S. H. (1999). A Theory of Cultural Values and Some Implications for Work. Applied Psychology: An International Review, 48(1), 23-47.

Sok, J., Blomme, R., \& Tromp, D. (2013). The use of the psychological contract to explain self-perceived employability. International Journal of Hospitality Management, 34, 274-284.

Sortheix, F. M., Dietrich, J., Chow, A., \& Salmelo-Aro, K. (2013). The role of career values for work engagement during the transition to working life. Journal of Vocational Behavior, 83(3), 466-475.

Triandis, H. C. (2001). Individualism-Collectivism and Personality. Journal of Personality, 69(6), 907-924.

Trice, H. M., \& Beyer, J. M. (1993). The Cultures of Work Organizations. Englewood Cliffs, NJ: Prentice Hall.

Wright, T. A., \& Cropanzano, R. (2000). Psychological well-being and job satisfaction as predictors of job performance. Journal of Occupational Health Psychology, 5(1), 84 -94.

Wüst, K. \& Simic, M. L. (2017). Students' Career Preferences: Intercultural Study of Croatian and German Students. Economics and Sociology, 10(3), 136-152.

Yi, X., Ribbens, B., Fu, L., \& Cheng, W. (2015). Variation in career and workplace attitudes by generation, gender, and culture differences in career perceptions in the United States and China. Employee Relations, 37(1), 66-82. 
Yoo, B., Donthu, N., \& Lenartowicz, T. (2011). Measuring Hofstede's Five Dimensions of Cultural Values at the Individual Level: Development and Validation of CVSCALE. Journal of International Consumer Marketing, 23(3), 193-210.

\section{TÜRKÇE GENİ̧ ÖZET}

Her türlü sosyal olgunun öncülü olma potansiyeli taşıyan kültürel değerlerin birey tutum ve davranışları üzerine muhtemel etkilerini incelemek, kişilerin davranış kalıplarını açıklamada yarar sağlayabileceği gibi mikro ölçekte örgütlerde karşılaşılabilecek sorunları tespit etmede ve önlemede de aslında önemli bir araç niteliği taşımaktadır. Kültürel değerlerin birey düşünce sistemi, tutum, tercih, değerler ve davranışlara etkilerinin belirlenmesi, örgütlere proaktif düşünme becerisi kazandırdığı gibi aynı zamanda da pratik uygulamalara rehberlik etme potansiyeli taşımaktadır. Bireylerin kültürel değerleri, iş, yaşam, aile, toplum ve kariyer gibi geniş ölçekte birçok alanla ilgili değerlerini de etkilemeyebilmektedir (Aycan ve Fikret Pasa, 2003, s. 32; Schwartz, 1999, s. 25). Yazın incelendiğinde kariyer değerleri kişilik, yetenek, yetiştirilme tarzı, eğitim düzeyi gibi faktörlerle ilişkili bulunmuştur (Nordvik, 1996). Bu noktada sorulması gereken temel hususlardan biri de bireyin kültürel değerlerinin kariyer değerlerinin inşasında rolü olup olmadığıdır. Bu konuda teorik bir takım çıkarım yapmak mümkün olsa da yeterli ampirik birikim bulunmamaktadır (Marshall ve Bonner, 2003, s. 283). Bu gerekçe ile bu çalışmada Hofstede'nin kültürel değerlerinin bireylerin kariyer değerlerine muhtemel etkilerinin incelenmesi amaçlanmıştır. Ataerkil bir toplum olarak bilinen Türk toplumu genel olarak toplulukçu, güç mesafesi ve belirsizlikten kaçınma boyutları yüksek bir toplumdur (Hofstede, 2001). Bu çalışmada yalnızca bu bağlamda toplulukçuluk, güç mesafesi ve belirsizlikten kaçınma değerlerine odaklanılmıstır. Kariyer değerleri ise Delong'un (1982) öne sürdüğü üzere teknik-fonksiyonel, yönetim becerisi, otonomi, güvence ve istikrar, girişimci, kimlik, çeşitlilik ve hizmet olarak ele alınmıştır.

Konuyla ilgili ampirik çalışmaların sınırlı olmasından dolayı hipotez geliştirme aşamasında kültürel değerlerin her bir kariyer değerine olası etkileri ilgili yazın bağlamında tartışılmış ve bazı teorik çıkarımlar yapılmıştır. Fakat kültürel değerlerin bazı kariyer değerlerine etkilerine yönelik net çıkarımlar yapılamadığ1 için çalışmanın hipotezleri yönsüz olarak geliştirilmiş ve bu bağlamda keşfedici nitelik taşımaktadır. Çalışmanın hipotezleri ana ve alt olmak üzere şu şekilde formüle edilmiştir.

H1: Kültürel değerler kariyer değerlerini etkilemektedir.

H1a: Güç mesafesi kariyer değerlerini etkilemektedir.

H1b: Toplulukçuluk kariyer değerlerini etkilemektedir.

H1c: Belirsizlikten kaçınma kariyer değerlerini etkilemektedir.

Çalışmanın amacına yönelik olarak nicel bir araştırma tasarlanmış ve bu bağlamda nicel analiz yöntemlerinden yararlanılmıştır. Araştırma için gerekli veriler Kocaeli ve Sakarya illerinde farklı sektörlerde faaliyet gösteren işletmelerin çalışanlarından elde edilmiştir. Kocaeli ve Sakarya illeri sanayilerinin nispeten daha gelişmiş olması nedeniyle sürekli göç aldığından Türkiye'nin her kesimin bir arada yaşadığı, kültürel açıdan kozmopolit illerdir. Bu bakımdan bu iki ilden elde edilecek verilerin kültürel açıdan Türk çalışanları temsil edebileceği düşünülmüştür. Araştırmanın örneklemini 274 çalışan oluşturmaktadır. Veriler anket tekniği vasıtasıyla elde edilmiştir. Ankette yer alan ölçekler geçerliliği test edilmiş ölçeklerdir. Çalışanların kültürel değerlerini ölçmek üzere Yoo, Donthu ve Lenartowicz (2011) tarafindan geliştirilmiş ölçek kullanılmıştır. Ölçek kültürel değerleri bireysel düzeyde ele almaktadır. Orijinal ölçek 26 ifadeden oluşmaktadır. Bu araştırma kapsamında yalnızca toplulukçuluk (6), güç mesafesi (5) ve belirsizlikten kaçınma (5) boyutları olmak üzere toplam 16 ifadeden yararlanılmıştır. Ölçeğin Türkçeye uyarlaması Saylık (2017) tarafindan yapılmıştır. Uyarlanmış ölçeğin kullanımı için araştırmacıdan gerekli izin alınmıştır. Çalışanların kariyer değerlerini ölçmek için ise Delong (1982) tarafindan geliştirilen ölçek kullanılmıştır. İlgili ölçek teknik-fonksiyonel, otonomi, hizmet, kimlik, girişimci, güvence ve istikrar, genel yönetim becerisi ve çeşitlilik olmak üzere sekiz boyuttan ve 38 ifadeden oluşmaktadır. Tarafımızca gerçekleştirilen faktör analizi ve içsel tutarllık testlerinde de ölçeklere ilişkin tatmin edici sonuçlar elde edilmiştir.

Araştırmanın hipotezlerini test etmek üzere çoklu regresyon analizinden yararlanılmıştır. Bu aşamada kültürel değerler bağımsız değişkenler ve her bir kariyer değeri bağımlı değişken olmak üzere 8 ayrı model oluşturulmuştur. Bulgulara göre, beklendiği üzere çalışanların güç mesafesi değerleri teknik-fonksiyonel, yönetim becerisi ile kimlik kariyer değerlerini pozitif yönde, hizmet kariyer değerini ise negatif etkilemektedir. Öte yandan güç mesafesi değerinin otonomi, güvence ve istikrar, girişimcilik ve çeşitlilik kariyer değerleri üzerinde anlamlı etkilerine rastlanmamıştır. Toplulukçuluk kültürel değeri teknik- 
fonksiyonel, yönetim becerisi ve hizmet kariyer değerlerini olumlu yönde etkilerken, diğer kariyer değerlerine olan etkileri anlamsız bulunmuştur. Son olarak çalışanların belirsizlikten kaçınma değerleri güvence ve istikrar, girişimcilik, kimlik ve hizmet kariyer değerlerini pozitif etkilemektedir. Öte yandan belirsizlikten kaçınmanın teknik-fonksiyonel, yönetim becerisi, otonomi ve çeşitlilik kariyer değerlerine anlamlı etkileri gözlemlenmemiştir. Bulguların çoğunluğu beklenen yönde olsa da, belirsizlikten kaçınmanın girişimcilik kariyer değerine pozitif etkisi yazından farklı bir görünüm çizmiştir. Normal şartlarda risk almaktan kaçınan bireylerin girişimcilik değerlerinin düşük olması beklenir. Belki burada işten çıkarılma ve güvence ve istikrarı sağlayama gibi korkuların bireyleri bilinçaltında ve bilinç düzeyinde kendi işlerini kurmaya yönelttiği düşünülebilir. Burada risk almanın tam anlamına odaklanmak ve bağlamsal olarak değerlendirmek gereklidir. Sonuç itibariyle güvence ve istikrarı sağlama arzusu da aslında riskten kaçınmadır ve kişi sırf başkalarının emrinde çalışmayı bir risk olarak düşünüp girişimci olmayı tercih edebilir. Bu bağlamda girişimci olmak aslında riski bertaraf etme olarak algılanabilir. Çalışmanın bulguları Türk toplumunu karakterize eden güç mesafesi, toplulukçuluk ve belirsizlikten kaçınmanın bireylerin kariyer değerleri üzerinde kısmi etkili olduğunu ortaya koymaktadır. Bulguları teorik ve pratik açıdan çeşitli imalar sunmaktadır. İlk olarak bu çalışma kültürel değerlerin kısmi de olsa kariyer değerleri üzerinde etkili olan önemli faktör olduğunu kanıtlamaktadır. Kültür bir şekilde bireylerin farklı alanlardaki değerlerini etkilemektedir. Kültürel değerlerin tanımlanması, kariyer değerleri ile bağlantılarının saptanması ile çalışanların başarılı olması muhtemel istihdam alanları belirlenebilir. Henüz kariyer hedeflerini belirlememiş, keşfetme ve kurma aşamasındaki bireyler açısından kültürel değerlerin belirlenmesi bu anlamda faydalı olabilir. Keşfedici niyetle yürütülen bu araştırmanın bulguları elbette yazına katkı sağlama güdüsüyle gerçekleştirilmiştir. Fakat kültürel değerler ve kariyer değerleri etkileşimine yönelik daha birçok teorik ve ampirik nitelikte çalışmalara ihtiyaç olduğu aşikardır. 